\title{
Effects of $\mathrm{As}_{2} \mathrm{O}_{3}$ nanoparticles on cell growth and apoptosis of NB4 cells
}

\author{
XIAOYAN DONG, NING MA, MENGMENG LIU and ZILING LIU \\ Department of Hematological Neoplasms, The First Affiliated Hospital of Jilin University, \\ Changchun, Jilin 130021, P.R. China
}

Received August 29, 2014; Accepted June 22, 2015

DOI: $10.3892 /$ etm.2015.2651

\begin{abstract}
The aim of the present study was to explore the preparation of arsenic trioxide $\left(\mathrm{As}_{2} \mathrm{O}_{3}\right)$ nanoparticles and examine the antitumor effects of these nanoparticles on $\mathrm{NB} 4$ cells. $\mathrm{As}_{2} \mathrm{O}_{3}$ nanoparticles were prepared using the sol-gel method and characterized using transmission electron microscopy and energy dispersive spectroscopy. The results indicated that the $\mathrm{As}_{2} \mathrm{O}_{3}$ nanoparticles prepared in the present study were round or elliptical, well dispersed and had an $\sim 40$-nm or $<10$-nm diameter. The antitumor effects of $\mathrm{As}_{2} \mathrm{O}_{3}$ nanoparticles at various concentrations were analyzed by flow cytometry and the MTT assay, and were compared with those of traditional $\mathrm{As}_{2} \mathrm{O}_{3}$ solution. At the same concentration and incubation time $(48 \mathrm{~h})$, the survival rate of cells treated with $\mathrm{As}_{2} \mathrm{O}_{3}$ nanoparticles was significantly lower than that of cells treated with the $\mathrm{As}_{2} \mathrm{O}_{3}$ solution. The growth inhibition rate under both treatments was time- and dose-dependent. In addition, at the same concentration and incubation time, the apoptosis rate of the cells treated with $\mathrm{As}_{2} \mathrm{O}_{3}$ nanoparticles was significantly higher than that of the cells treated with the $\mathrm{As}_{2} \mathrm{O}_{3}$ solution. Furthermore, $\mathrm{As}_{2} \mathrm{O}_{3}$ nanoparticles resulted in a greater reduction in the expression of the anti-apoptotic protein B-cell lymphoma 2 compared with the $\mathrm{As}_{2} \mathrm{O}_{3}$ solution. In conclusion, $\mathrm{As}_{2} \mathrm{O}_{3}$ nanoparticles, prepared using the sol-gel method, were found to produce a stronger cytotoxic effect on tumor cells than that produced by the $\mathrm{As}_{2} \mathrm{O}_{3}$ solution, possibly by inhibiting Bcl-2 expression.
\end{abstract}

\section{Introduction}

Acute promyelocytic leukemia (APL) is a subtype of acute myelogenous leukemia, accounting for $6.2-40.2 \%$ of acute

Correspondence to: Dr Ziling Liu, Department of Hematological Neoplasms, The First Affiliated Hospital of Jilin University, 71 Xinmin Street, Changchun, Jilin 130021, P.R. China

E-mail: zilingliu@yahoo.com.cn

Key words: arsenic trioxide, nanotechnology, NB4 cells, growth inhibition, apoptosis myelogenous leukemia cases. APL manifests rapidly, causing serious illness, and is often accompanied by severe bleeding and disseminated intravascular coagulation. In the past, APL was considered to be 'the most malignant form of acute leukemia' $(1,2)$. APL cells are relatively sensitive to chemotherapy (CT); however, it has been frequently observed that CT aggravates bleeding disorders, leading to high early-mortality rates. Despite the sensitivity of APL to $\mathrm{CT}$, the median duration of remission ranges between 11 and 25 months, and only $35-45 \%$ of the patients are cured by CT alone $(3,4)$.

Arsenic trioxide $\left(\mathrm{As}_{2} \mathrm{O}_{3}\right)$ is the primary active component in arsenic. Arsenic is a common, naturally occurring substance that exists in organic and inorganic forms. It has been demonstrated that $\mathrm{As}_{2} \mathrm{O}_{3}$ can induce cell differentiation and apoptosis. $\mathrm{As}_{2} \mathrm{O}_{3}$ yields a remission rate of as high as $90 \%$ in treating APL $(5,6)$. The traditional $\mathrm{As}_{2} \mathrm{O}_{3}$ solution, however, has numerous side effects, such as hyperleukocytosis, liver and kidney dysfunction, and effusion $(7,8)$. These side effects increase the suffering of patients with APL, which sometimes results in patients decreasing the dose of $\mathrm{As}_{2} \mathrm{O}_{3}$ or even stopping halfway through therapy, thus seriously affecting its curative effects. The aforementioned reasons limit the use of $\mathrm{As}_{2} \mathrm{O}_{3}$ in clinical practice; therefore, developing new methods of $\mathrm{As}_{2} \mathrm{O}_{3}$ administration that avoid these side effects is imperative. Nanomedicine has attracted considerable focus due to its beneficial characteristics, including targeted drug delivery and slow drug release (9). Employing nanotechnology in cancer treatment is currently one of the most cutting-edge fields of biotechnology research $(10,11)$. In the present study, the traditional $\mathrm{As}_{2} \mathrm{O}_{3}$ preparation technology was modified, and $\mathrm{As}_{2} \mathrm{O}_{3}$ nanoparticles were prepared using modern nanotechnology. The aim of the present study was to evaluate the properties of the prepared $\mathrm{As}_{2} \mathrm{O}_{3}$ nanoparticles and investigate their antitumor effects. We hypothesized that the modified preparation technique would improve bioavailability, which would reduce the drug dosage and toxicity and enhance the associated curative effects.

\section{Materials and methods}

Cells and cell culture. NB4 cells, a human APL cell line, were provided by $\mathrm{Dr}$ Jifan $\mathrm{Hu}$ at Stanford University Medical School (Palo Alto, CA, USA) and maintained in the 
laboratory of The First Affiliated Hospital of Jilin University (Changchun, China). The cells were cultured at $37^{\circ} \mathrm{C}$ in Iscove's Modified Dulbecco's Medium (Gibco-BRL, Grand Island, NY, USA), supplemented with $10 \%$ heat-inactivated fetal bovine serum (Hanzhou Sijiqing Biological Engineering Materials Co., Ltd., Hanzhou, China), $100 \mathrm{U} / \mathrm{ml}$ penicillin and $100 \mu \mathrm{g} / \mathrm{ml}$ streptomycin in an atmosphere of $5 \% \mathrm{CO}_{2}$ and $100 \%$ humidity.

Preparation of $\mathrm{As}_{2} \mathrm{O}_{3}$ nanoparticles using the sol-gel method. For the preparation method, the following formulae, in which

$$
\begin{aligned}
& \mathrm{M}(\mathrm{OR})_{\mathrm{n}}+\mathrm{xH}_{2} \mathrm{O} \rightarrow \mathrm{M}(\mathrm{OH})_{\mathrm{x}}(\mathrm{OR})_{(\mathrm{n}-\mathrm{x})}+\mathrm{xROH} \\
& \mathrm{M}(\mathrm{OH})_{\mathbf{x}}(\mathrm{OR})_{(\mathrm{n}-\mathrm{x})} \rightarrow(\mathrm{x}-\mathrm{n} / 2) \mathrm{H}_{2} \mathrm{O}+(\mathrm{n}-\mathrm{x}) \mathrm{ROH}+\mathrm{M}_{\mathrm{x}} \mathrm{O}_{\mathrm{n} / 2}
\end{aligned}
$$

$M$ represents the metal element and $R$ represents $C_{m} H_{2 m+1}$, were used (12):

The specific preparation method was as follows: All items used in the tests were sterilized, and $\mathrm{As}_{2} \mathrm{O}_{3}$ powder and hydrochloric acid were magnetically stirred and mixed at a mass/volume ratio of 1:0.02-0.1 for 10-30 min. Ethanol was then added at a volume ratio of 1:5-10, the solution was stirred for $20-30 \mathrm{~min}$ at $50-60^{\circ} \mathrm{C}$ and the mixture was sonicated for $5 \mathrm{~min}$. Finally, distilled water was added at a volume ratio of 1:4-5, and the mixture was sonicated for 10-20 min. Following preparation, a few drops of the sample were placed on a copper mesh, dried and then characterized with transmission electron microscopy (TEM; JEM-2010, JEOL Ltd., Tokyo, Japan), scanning electron microscopy (JSM-840, JEOL Ltd.) and energy dispersive spectrometry (EDS; JEOL Ltd.).

Cytotoxicity analysis. The cytotoxicity and sensitivity of $\mathrm{As}_{2} \mathrm{O}_{3}$ (Institute for Drug Control of the Ministry of Health of China) and $\mathrm{As}_{2} \mathrm{O}_{3}$ nanoparticles were measured using the MTT cell viability method (13). Cells were divided into three groups: $\mathrm{NB} 4, \mathrm{NB} 4+\mathrm{As}_{2} \mathrm{O}_{3}$ and $\mathrm{NB} 4+\mathrm{As}_{2} \mathrm{O}_{3}$ nanoparticles. NB4 cells in the logarithmic growth phase were seeded on 96-well plates in quadruplicate at a density of $1 \times 10^{5} /$ well in $100 \mu \mathrm{l} . \mathrm{As}_{2} \mathrm{O}_{3}$ solution and $\mathrm{As}_{2} \mathrm{O}_{3}$ nanoparticles ( 7 different final concentrations: $0.25,0.5,1.0,1.5,3.0,6.0$ and $12.0 \mu \mathrm{mol} / \mathrm{l})$ were added at the appropriate time points according to the group setting. After 24, 48, 72 and $96 \mathrm{~h}$ of treatment, the cells were incubated for $4 \mathrm{~h}$ with MTT (Changchun Biotech Co., Ltd., Changchun, China) and then lysed with acidified isopropanol. Absorbance was measured at $570 \mathrm{~nm}$. The inhibition rate was calculated using the following formula: Inhibition rate $=[($ absorbance value of control group - absorbance value of test group)/absorbance value of control group] x100\%. All experiments were repeated three times.

Flow cytometric analysis. Cell apoptosis was quantified using flow cytometry (FCM; FACSCalibur ${ }^{\mathrm{TM}}$, BD Biosciences, San Jose, CA, USA). Cells were grouped as previously described for the cytotoxicity analysis. Both the $\mathrm{As}_{2} \mathrm{O}_{3}$ solution and $\mathrm{As}_{2} \mathrm{O}_{3}$ nanoparticles were tested at two concentrations: 1.5 and $3.0 \mu \mathrm{mol} / 1$. Following incubation at $37^{\circ} \mathrm{C}$ in an atmosphere of $5 \% \mathrm{CO}_{2}$ and $100 \%$ humidity for $48 \mathrm{~h}$, the cells were washed with cold phosphate-buffered saline (PBS) twice and resuspended in cold PBS. The apoptosis rate of NB4 cells after treatment was examined using an Annexin V/Propidium Iodide Apoptosis Detection Assay kit (Beyotime Institute of Biotechnology Co., Shanghai, China). All experiments were repeated three times.

Western blot analysis. Cells were grouped and pretreated as previously described in the FCM. The total protein was extracted, separated using SDS-PAGE and transferred to a nitrocellulose membrane. The membrane was blocked with $5 \%$ skimmed milk at room temperature for $2 \mathrm{~h}$, and then stained with rabbit polyclonal anti-B-cell lymphoma 2 (Bcl-2; 1:200; BA0412) or mouse monoclonal anti- $\beta$-actin antibodies (1:200; BM0627; Wuhan Boster Biotechnology Co., Ltd., Wuhan, China) for $2 \mathrm{~h}$ at room temperature. Following washing, the membrane was incubated with horseradish peroxidase-labeled goat-anti-rabbit IgG (Sigma-Aldrich, St. Louis, MO, USA) at 1:1,000 for $1 \mathrm{~h}$ at room temperature. The membrane was then washed and developed. All experiments were repeated three times.

Statistical analysis. All data were analyzed using SPSS 13.0 software (SPSS Inc., Chicago, IL, USA). A $t$-test was adopted to analyze inter-group differences. $\mathrm{P}<0.05$ was considered to indicate a statistically significant difference.

\section{Results}

Characteristics of the $\mathrm{As}_{2} \mathrm{O}_{3}$ nanoparticles. As observed using TEM, the $\mathrm{As}_{2} \mathrm{O}_{3}$ powder was square, polygonal or in the form of anomalistic crystals with high electron density (Fig. 1A). The average diameter of the $\mathrm{As}_{2} \mathrm{O}_{3}$ powder was $>1 \mu \mathrm{m}$. By contrast, the $\mathrm{As}_{2} \mathrm{O}_{3}$ nanoparticles were well dispersed, approximately spherical or elliptical and 40 or $<10 \mathrm{~nm}$ in diameter (Fig. 1B). The EDS results confirmed that these nanoparticles were $\mathrm{As}_{2} \mathrm{O}_{3}$ (Fig. 2).

NB4 cell morphological changes. The morphological changes of the NB4 cells were compared following treatment with $\mathrm{As}_{2} \mathrm{O}_{3}$ or $\mathrm{As}_{2} \mathrm{O}_{3}$ nanoparticles, and the results are shown in Fig. 3. The NB4 cells in the control group exhibited a normal shape with similar sizes and clear edges (Fig. 3A). No cell fragmentation was observed (Fig. 3A). Forty-eight hours after $\mathrm{As}_{2} \mathrm{O}_{3}$ solution treatment $(1.5 \mu \mathrm{mol} / \mathrm{l})$, the NB4 cells were found to be reduced in number and volume and to exhibit irregular shapes (Fig. 3B). In addition to the changes described above, the number of necrotic cells and cell fragments increased during incubation at $3.0 \mu \mathrm{mol} / \mathrm{l}$ (Fig. 3D). Using the same concentrations and incubation time, the morphological changes were more marked following treatment with $\mathrm{As}_{2} \mathrm{O}_{3}$ nanoparticles (Fig. 3C and E).

$\mathrm{As}_{2} \mathrm{O}_{3}$ nanoparticles inhibit $\mathrm{NB} 4$ cell growth. The results indicated that the $\mathrm{As}_{2} \mathrm{O}_{3}$ nanoparticles were more effective than the $\mathrm{As}_{2} \mathrm{O}_{3}$ solution in inhibiting NB4 cell growth. At the same concentration and incubation time, the growth rate of cells treated with $\mathrm{As}_{2} \mathrm{O}_{3}$ nanoparticles was significantly lower than that of cells treated with the $\mathrm{As}_{2} \mathrm{O}_{3}$ solution. In both groups, the inhibition rate was time- and dose-dependent (Fig. 4).

$\mathrm{As}_{2} \mathrm{O}_{3}$ nanoparticles induce $\mathrm{NB} 4$ cell apoptosis. $\mathrm{As}_{2} \mathrm{O}_{3}$ nanoparticles appeared to be more effective than $\mathrm{As}_{2} \mathrm{O}_{3}$ 


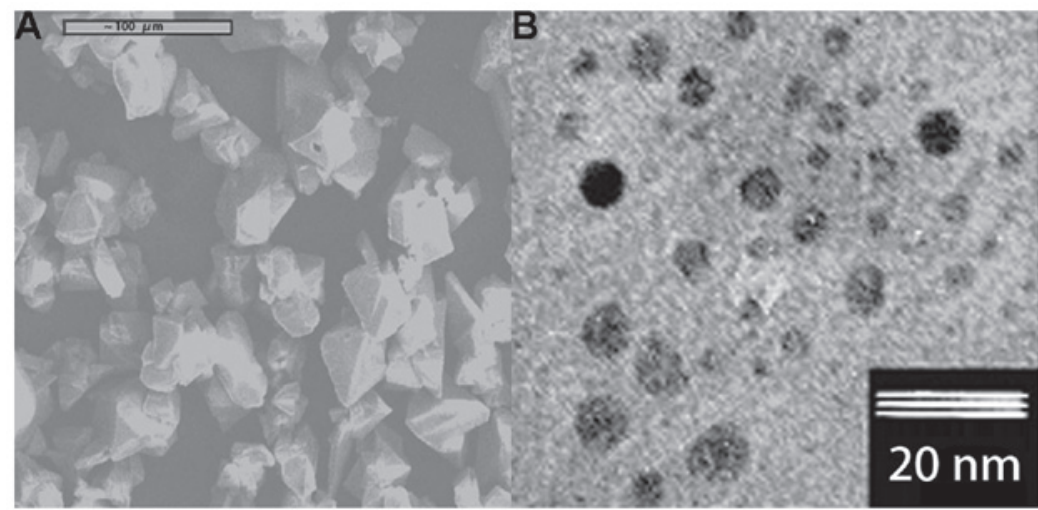

Figure 1. Morphology of $\mathrm{As}_{2} \mathrm{O}_{3}$ powder and nanoparticles. (A) $\mathrm{As}_{2} \mathrm{O}_{3}$ powder under scanning electron microscopy (magnification, $\left.\mathrm{x} 10,000\right) ;(\mathrm{B}) \mathrm{As} \mathrm{O}_{3}$ nanoparticles $(<10 \mathrm{~nm}$ ) under transmission electron microscopy (magnification, $\mathrm{x} 300,000)$. $\mathrm{As}_{2} \mathrm{O}_{3}$, arsenic trioxide.

A counts

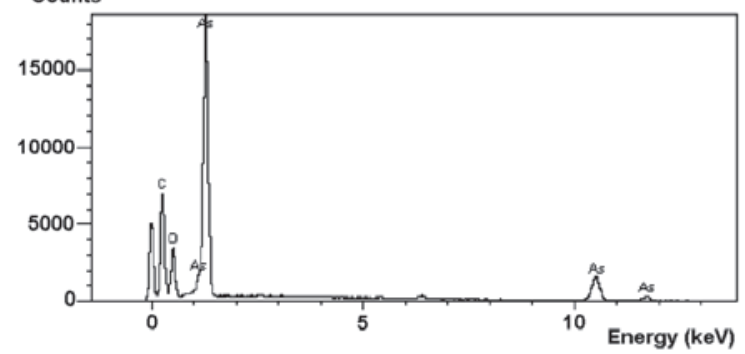

B Counts

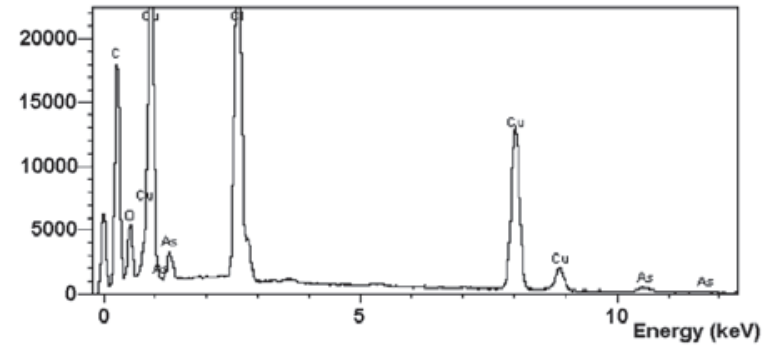

Figure 2. Energy dispersive spectrometry results of (A) $\mathrm{As}_{2} \mathrm{O}_{3}$ powder and (B) $\mathrm{As}_{2} \mathrm{O}_{3}$ nanoparticles. $\mathrm{As}_{2} \mathrm{O}_{3}$, arsenic trioxide.
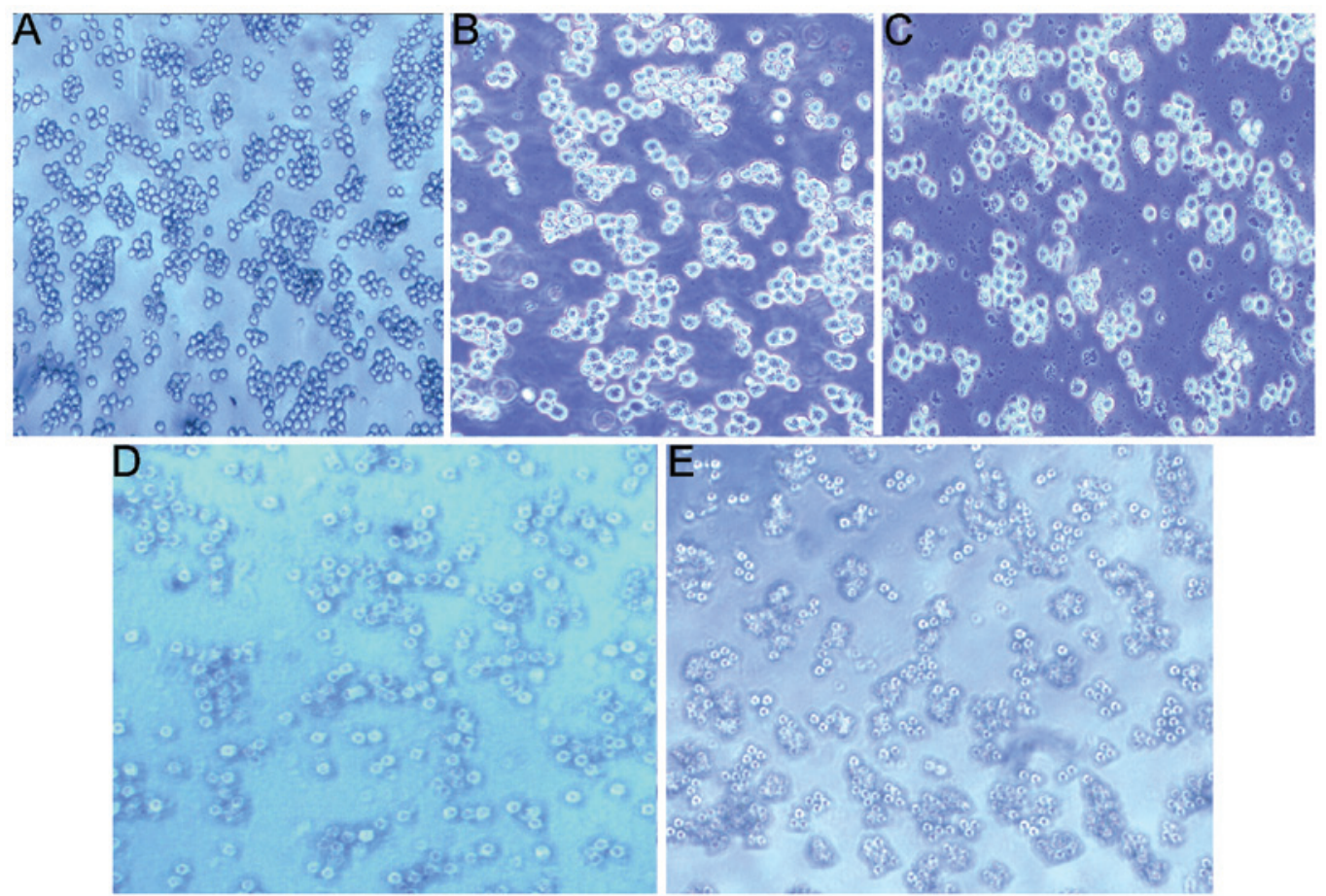

Figure 3. Optical inverted microscopy images of NB4 cells incubated with $\mathrm{As}_{2} \mathrm{O}_{3}$ solution or $\mathrm{As}_{2} \mathrm{O}_{3}$ nanoparticles for $48 \mathrm{~h}$ (magnification, x40). NB4 cells were treated as follows: (A) Control, (B) $\mathrm{As}_{2} \mathrm{O}_{3}$ solution (1.5 $\left.\mu \mathrm{mol} / \mathrm{l}\right)$, (C) $\mathrm{As}_{2} \mathrm{O}_{3}$ nanoparticles (1.5 $\left.\mu \mathrm{mol} / \mathrm{l}\right),(\mathrm{D}) \mathrm{As}_{2} \mathrm{O}_{3}$ solution (3.0 $\left.\mu \mathrm{mol} / \mathrm{l}\right)$ and (E) $\mathrm{As}_{2} \mathrm{O}_{3}$ nanoparticles $(3.0 \mu \mathrm{mol} / \mathrm{l}) . \mathrm{As}_{2} \mathrm{O}_{3}$, arsenic trioxide.

solution in inducing apoptosis of NB4 cells. Using the same concentration and incubation time, the apoptosis level of cells treated with $\mathrm{As}_{2} \mathrm{O}_{3}$ nanoparticles was significantly higher than that of cells treated with the $\mathrm{As}_{2} \mathrm{O}_{3}$ solution (Fig. 5). 

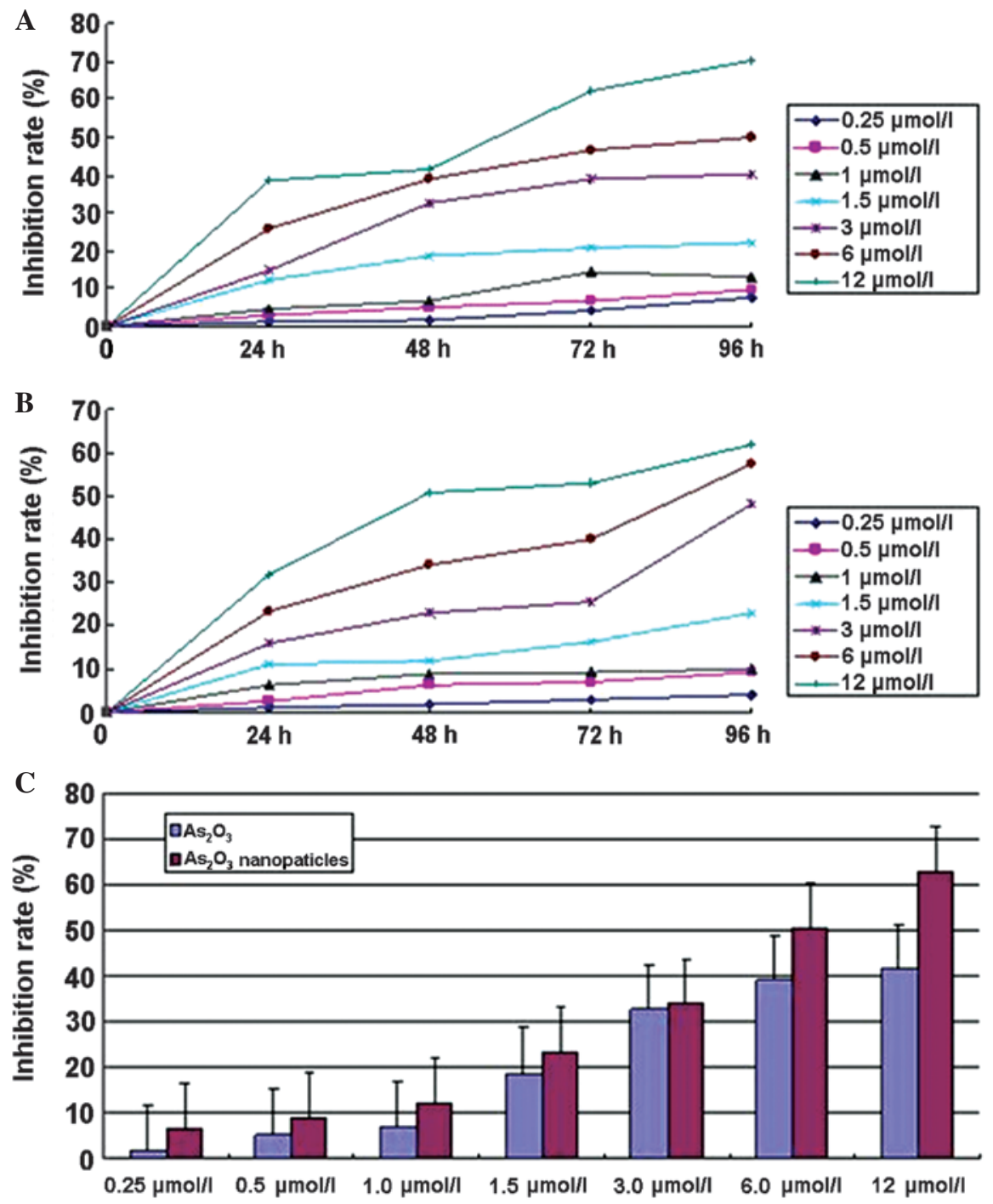

Figure 4. Comparison between the growth-inhibition effects of $\mathrm{As}_{2} \mathrm{O}_{3}$ solution and nanoparticles. The growth-inhibition effects of $\mathrm{As}_{2} \mathrm{O}_{3}$ solution and nanoparticles on NB4 cells were compared at different incubation time-points $\left(24,48,72\right.$ and 96 h). Growth-inhibitory effects of $(\mathrm{A}) \mathrm{As}_{2} \mathrm{O}_{3}$ solution and (B) $\mathrm{As}_{2} \mathrm{O}_{3}$ nanoparticles. (C) Following the treatment of NB4 cells with $\mathrm{As}_{2} \mathrm{O}_{3}$ solution or nanoparticles for $48 \mathrm{~h}$ at different concentrations, the growth-inhibitory effects were compared. $\mathrm{As}_{2} \mathrm{O}_{3}$, arsenic trioxide.

$\mathrm{As}_{2} \mathrm{O}_{3}$ nanoparticles downregulate Bcl-2 expression. The promotion of apoptosis by $\mathrm{As}_{2} \mathrm{O}_{3}$ was further explored by examining the expression level of the anti-apoptotic protein Bcl-2, which has been implicated in several types of cancer (14). The results showed that, during incubation at $3.0 \mu \mathrm{mol} / 1, \mathrm{As}_{2} \mathrm{O}_{3}$ nanoparticles caused a more significant reduction in Bcl-2 expression compared with the $\mathrm{As}_{2} \mathrm{O}_{3}$ solution (Fig. 6).

\section{Discussion}

$\mathrm{As}_{2} \mathrm{O}_{3}$ is the primary active component in arsenic. In Traditional Chinese Medicine, arsenic has been shown to exhibit excellent efficacy in treating APL (15). $\mathrm{As}_{2} \mathrm{O}_{3}$ acts on APL cells by promoting differentiation, as well as by inhibiting growth and inducing apoptosis. Arsenic acid, however, is a highly toxic substance and its clinical application is therefore limited due to its severe side effects, which include serious heart toxicity, cavity effusion, liver and kidney damage, gastrointestinal adverse reactions and peripheral nervous infection $(16,17)$. It is therefore important to develop new formulations of $\mathrm{As}_{2} \mathrm{O}_{3}$ with high efficiency and low toxicity.

Nanotechnology is a technologically advanced field that manipulates atoms and molecules on a spatial scale ranging from 0.1 to $100 \mathrm{~nm}$ in order to serve specific functions. Changing the traditional drug preparation technology by adopting modern nanotechnology improves bioavailability by promoting drug absorption by cells from the tissue space. Nanotechnology also enables slow drug release, increasing drug concentrations in the lesion site, reducing drug dosage and toxicity in non-targeted sites and enhancing the curative effects. The sol-gel method is one of the most common methods for preparing nanomaterials (18).

In the present study, $\mathrm{As}_{2} \mathrm{O}_{3}$ nanoparticles, measuring $<10 \mathrm{~nm}$ and $\sim 40 \mathrm{~nm}$ in diameter, were successfully prepared using the sol-gel method. The results showed that, compared with the $\mathrm{As}_{2} \mathrm{O}_{3}$ solution, the $\mathrm{As}_{2} \mathrm{O}_{3}$ nanoparticles resulted in more 


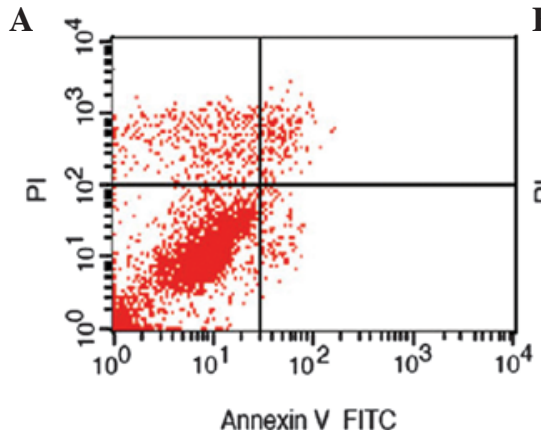

Annexin V FITC

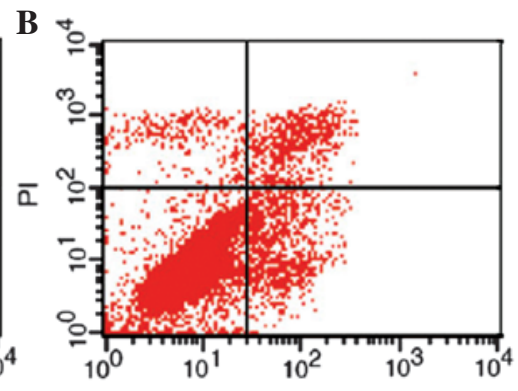

Annexin V FITC

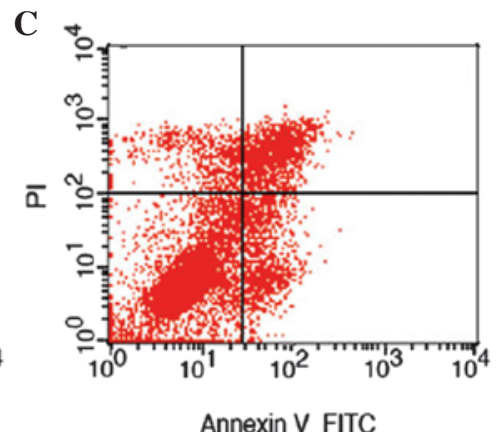

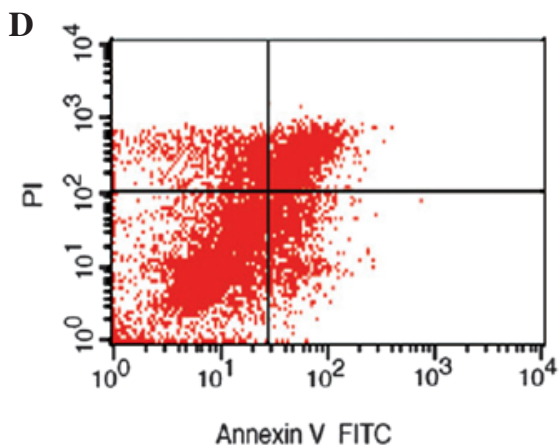

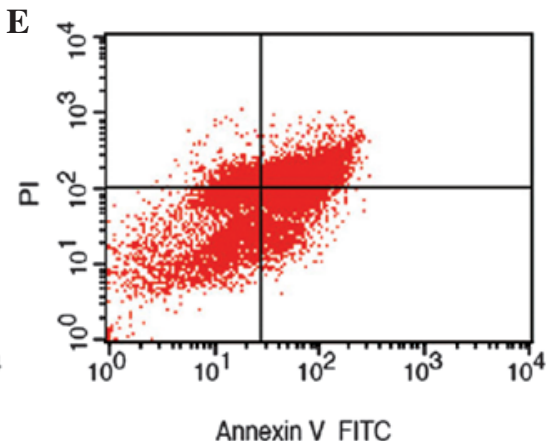

Figure 5. Apoptosis of NB4 cells $48 \mathrm{~h}$ after treatment with $\mathrm{As}_{2} \mathrm{O}_{3}$ solution or $\mathrm{As}_{2} \mathrm{O}_{3}$ nanoparticles. NB4 cells were treated as follows (the percentage of apoptotic cells is indicated): (A) Control, 0.86\%; (B) $\mathrm{As}_{2} \mathrm{O}_{3}$ solution (1.5 $\left.\mu \mathrm{mol} / \mathrm{l}\right), 8.60 \%$; (C) $\mathrm{As}_{2} \mathrm{O}_{3}$ nanoparticles (1.5 $\left.\mu \mathrm{mol} / \mathrm{l}\right), 10.44 \%$; (D) $\mathrm{As}_{2} \mathrm{O}_{3}$ solution (3.0 $\mu \mathrm{mol} / \mathrm{l}$ ), $10.34 \%$; (E) $\mathrm{As}_{2} \mathrm{O}_{3}$ nanoparticles $(3.0 \mu \mathrm{mol} / \mathrm{l}), 23.41 \%$. $\mathrm{As}_{2} \mathrm{O}_{3}$, arsenic trioxide; PI, propidium iodide; FITC, fluorescein isothiocyanate.

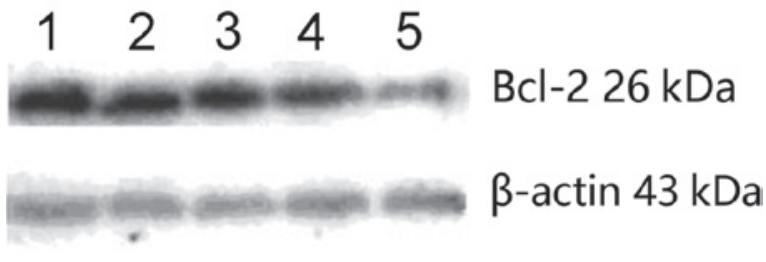

Figure 6. Bcl-2 expression of NB4 cells following treatment with $\mathrm{As}_{2} \mathrm{O}_{3}$ solution or $\mathrm{As}_{2} \mathrm{O}_{3}$ nanoparticles for $48 \mathrm{~h}$. NB4 cells were treated as follows: 1, Control; $2, \mathrm{As}_{2} \mathrm{O}_{3}$ solution $(1.5 \mu \mathrm{mol} / 1) ; 3, \mathrm{As}_{2} \mathrm{O}_{3}$ nanoparticles $(1.5 \mu \mathrm{mol} / 1)$; 4, $\mathrm{As}_{2} \mathrm{O}_{3}$ solution $(3.0 \mu \mathrm{mol} / \mathrm{l}) ; 5, \mathrm{As}_{2} \mathrm{O}_{3}$ nanoparticles $(3.0 \mu \mathrm{mol} / 1) . \mathrm{As}_{2} \mathrm{O}_{3}$, arsenic trioxide; Bcl-2, B-cell lymphoma 2.

significant morphological changes in the NB4 cells (Fig. 3), exhibited stronger growth-inhibition effects in the MTT assay (Fig. 4), induced apoptosis to a greater extent (Fig. 5) and caused greater downregulation of the anti-apoptotic protein Bcl-2 at high concentrations (Fig. 6). These findings were in agreement with a previous report that proposed that $\mathrm{As}_{2} \mathrm{O}_{3}$ induced apoptosis mainly through downregulating the expression of Bcl-2 (19).

The fact that the growth-inhibition and apoptosis-induction functions of $\mathrm{As}_{2} \mathrm{O}_{3}$ nanoparticles are more effective than those of the traditional $\mathrm{As}_{2} \mathrm{O}_{3}$ solution may be due to unique physical and chemical properties, including higher chemical activities; higher absorption and utilization; slow drug release, which helps maintain effective drug concentrations in vivo; increased ease of uptake by tumor cells and special pharmacological effects. The surface of nanoparticles can be modified chemically and biologically to generate nano-targeting drugs. In addition to the aforementioned inherent advantages of nanoparticles, nano-targeting drugs ensure targeted drug delivery, increasing curative effects and reducing drug dosages to mitigate or avoid side effects (20). The effectiveness of nanomedicine is directly associated with the size of the nanoparticles. A decrease in particle size causes an increase in surface area and, correspondingly, an increase in the number of surface atoms, leading to higher chemical activities. Small particles, however, are more prone to aggregation, which increases the total size of the particles and offsets the effects of increased chemical activity; therefore, when preparing small nanoparticles, it is necessary to adopt special methods of preventing aggregation. Ultrasonic dispersion is a common and effective method $(21,22)$. In the present study, $\mathrm{As}_{2} \mathrm{O}_{3}$ nanoparticles were prepared using the sol-gel method as previously described $(23,24)$. Unlike in previous studies, smaller-sized $\mathrm{As}_{2} \mathrm{O}_{3}$ nanoparticles $(<10 \mathrm{~nm})$ were prepared for the present experiments. The findings showed that small $\mathrm{As}_{2} \mathrm{O}_{3}$ nanoparticles $(<10 \mathrm{~nm})$ generate significant antitumor effects, even at low concentrations ( $1.5 \mu \mathrm{mol} / \mathrm{l})$, confirming that small $\mathrm{As}_{2} \mathrm{O}_{3}$ nanoparticles may have increased activity, thus requiring reduced dosages for cancer treatment.

In the present study, the traditional preparation technology was modified by employing modern nanotechnology, and smaller $\mathrm{As}_{2} \mathrm{O}_{3}$ nanoparticles were successfully prepared. The growth-inhibition and apoptosis-induction functions of $\mathrm{As}_{2} \mathrm{O}_{3}$ nanoparticles were further characterized, and the superiority of $\mathrm{As}_{2} \mathrm{O}_{3}$ nanoparticles over traditional $\mathrm{As}_{2} \mathrm{O}_{3}$ solutions in vitro was demonstrated. In conclusion, $\mathrm{As}_{2} \mathrm{O}_{3}$ nanoparticles are a promising approach for treating APL and the current data provide a theoretical and experimental basis for applying nanomedicine in the clinical treatment of acute leukemia. 


\section{Acknowledgements}

The authors would like to thank Medjaden Bioscience Limited for assisting in the preparation of this manuscript.

\section{References}

1. Hillestad LK: Acute promyelocytic leukemia. Acta Med Scand 159: 189-194, 1957.

2. Bernard J, Mathe G, Boulay J, Ceoard B and Chome J: Acute promyelocytic leukemia: A study made on 20 cases. Schweiz Med Wochenschr 89: 604-608, 1959 (In French).

3. Bernard J, Weil M, Boiron M, Jacquillat C, Flandrin G and Gemon MF: Acute promyelocytic leukemia: Results of treatment by daunorubicin. Blood 41: 489-496, 1973.

4. Ribeiro RC and Rego E: Management of APL in developing countries: Epidemiology, challenges and opportunities for international collaboration. Hematology Am Soc Hematol Educ Program: 162-168, 2006.

5. Zhang P, Wang SY, Hu LH, Shi FD, Qiu FG, Hong ZZ, Han XY, Yang H, Song YZ, Liu YP, et al: Arsenic trioxide treated 72 cases of acute promyelocytic leukemia. Zhong Hua Xue Ye Xue Za Zhi 17: 58-60, 1996 (In Chinese)

6. Wang ZY: Ham-Wasserman lecture: Treatment of acute leukemia by inducing differentiation and apoptosis. Hematology Am Soc Hematol Educ Program: 1-13, 2003.

7. Haverkamp W, Breithardt G, Camm AJ, Janse MJ, Rosen MR, Antzelevitch C, Escande D, Franz M, Malik M, Moss A and Shah R: The potential for QT prolongation and proarrhythmia by non-antiarrhythmic drugs: Clinical and regulatory implications Eur Heart J 21: 1216-1231, 2000.

8. Unnikrishnan D, Dutcher JP, Garl S, Varshneya N, Lucariello R and Wiernik PH: Cardiac monitoring of patients receiving arsenic trioxide therapy. Br J Haematol 124: 610-617, 2004.

9. Sinha R, Kim GJ, Nie S and Shin DM: Nanotechnology in cancer thearpeutics: Bioconjugated nanoparticles for drug delivery. Mol Cancer Ther 5: 1909-1917, 2006.

10. Ferrari M: Cancer nanotechnology: opportunities and challenges. Nat Rev Cancer 5: 161-171, 2005.

11. Sanna V, Pala N and Sechi M: Targeted therapy using nanotechnology: focus on cancer. Int J Nanomedicine 9: 467-483, 2014.

12. Song L: Preparation Method of Material. In: Materials Introduction Zhou DF (ed). Chemical Industry Press, Beijing, pp.119-121, 2001
13. Mosmann T: Rapid colorimetric assay for cellular growth and survival: Application to proliferation and cytotoxicity assays. J Immunol Methods 65: 55-63, 1983.

14. Mazel S, Burtrum D and Petrie HT: Regulation of cell division cycle progression by bcl-2 expression: a potential mechanism for inhibition of programmed cell death. J Exp Med 183: 2219-2226, 1996.

15. Zhang X, Yang L and Qiao Z: An analysis of the therapeutic effects and reactions in treating acute promyelocytic leukemia with intravenous arsenic trioxide or all-trans retinoic acid. Zhonghua Nei Ke Za Zhi 38: 113-115, 1999 (In Chinese).

16. Liu L, Qin SK, Chen HY, Wang J, Chen H, Ma J and Liu W: An experimental study on arsenic trioxide-selectively induced human hepatocarcinoma cell lines apoptosis and its related genes. Zhonghua Gan Zang Bing Za Zhi 8: 367-369, 2000 (In Chinese).

17. Huang SY, Chang CS, Tang JL, Tien HF, Kuo TL, Huang SF, Yao YT, Chou WC, Chung CY, Wang CH, et al: Acute and chronic arsenic poisoning associated with treatment of acute promyelocytic leukemia. Br J Haematol 103: 1092-1095, 1998.

18. $\mathrm{Hu} \mathrm{X}, \mathrm{Ma} \mathrm{L}$ and $\mathrm{Hu} \mathrm{N}$ : Ailing No. 1 in treating 62 cases of acute promyelocytic leukemia. Zhongguo Zhong Xi Yi Jie He Za Zhi 19: 473-476, 1999 (In Chinese).

19. Wang MD, Shin DM, Simons JW and Nie S: Nanotechnology for targeted cancer therapy. Expert Rev Anticancer Ther 7: 833-837, 2007.

20. Mathews V, George B, Lakshmi KM, Viswabandya A, Bajel A, Balasubramanian P, Shaji RV, Srivastava VM, Srivastava A and Chandy M: Single-agent arsenic trioxide in the treatment of newly diagnosed acute promyelocytic leukemia: Durable remissions with minimal toxicity. Blood 107: 2627-2632, 2006.

21. Huang YQ, Zhang YQ and Hua RQ: Preparation and properties of LLDPE/ Nano $\mathrm{SiO}_{2}$ composites. Zhong Guo Su Liao 17: 25, 2003 (In Chinese)

22. Zhao K, Chao YL and Yang Z: Development and property study of zirconia toughened nano-composite alumina ceramic powder for dental application. Zhonghua Kou Qiang Yi Xue Za Zhi 38: 384-386, 2003 (In Chinese)

23. Wang ZY, Zhang DS, Lu XL Yan SY, Jin LQ and Wan ML: Research of human liver cancer cell apoptosis induced by $\mathrm{As}_{2} \mathrm{O}_{3}$ nanoparticles. Yi Xue Yan Jiu Sheng Bao 18: 481-489, 2005 (In Chinese).

24. Wang Q, Wang ZY, Lin M, Zhang J, Zhao SS and Zhang DS: Application of $\mathrm{As}_{2} \mathrm{O}_{3}$ nanoparticles in treatment on human lung cancer in vivo and investigation of its anti-transfer mechanism. Na Mi Ji Shu He Jing Mi Gong Cheng 6: 99-102, 2008 (In Chinese). 